Hamdi Ben Yahia*

\title{
Crystal structure of a new polymorphic modification of $\mathrm{Na}_{2} \mathrm{Mn}_{3}\left(\mathrm{SO}_{4}\right)_{4}$
}

https://doi.org/10.1515/zkri-2019-0038

Received June 27, 2019; accepted October 8, 2019; published online October 28, 2019

\begin{abstract}
The new polymorph of $\mathrm{Na}_{2} \mathrm{Mn}_{3}\left(\mathrm{SO}_{4}\right)_{4}$ was prepared via solid state reaction route in a powder form and its crystals were grown by self-flux method. The crystal structure was determined from single crystal X-ray diffraction data. This polymorph crystallizes with an orthorhombic symmetry, space group $P b c a$, with $a=9.8313(4)$, $b=8.7467(3), c=29.6004(11) \AA, V=2545.38(17) \AA^{3}, Z=8$. Its structure refinement yielded the residual factors $R(F)=0.025$ and $w R\left(F^{2}\right)=0.065$ for 227 parameters and 2605 independent reflections at $2 \sigma(I)$ level. The use of group-subgroup schemes in the Bärnighausen formalism enabled an accurate comparison of the Pbca- and Cmc2-polymorphs of $\mathrm{Na}_{2} \mathrm{Mn}_{3}\left(\mathrm{SO}_{4}\right)_{4}$. Both polymorphs contain similar $\left[\mathrm{Mn}_{3}\left(\mathrm{SO}_{4}\right)_{4}\right]^{2-}$ building blocks formed of $\mathrm{Mn}_{2} \mathrm{O}_{11}$ dimer units and $\mathrm{MnO}_{5}$ trigonal pyramids that are interconnected by sharing corners with the $\mathrm{SO}_{4}$ tetrahedra. However, the stacking of these building blocks along the longest axes of the Pbca- and $\mathrm{Cmc2}_{1}$-structures is different. This induces differences in the coordination of the sodium atoms and in the orientation of the $\mathrm{SO}_{4}$ tetrahedra.
\end{abstract}

Keywords: polymorphism; self-flux crystal growth method; single crystal structure; sulphate.

\section{Introduction}

Polyanionic transition-metal phosphates have been subjected to growing scientific interest as electrode materials for lithium and sodium-ion batteries [1, 2]. Similarly, sulfate salts underwent a true renaissance when interesting electrochemical properties were discovered in sodium iron sulfate compounds. Indeed, the kröhnkite-type $\mathrm{Na}_{2} \mathrm{Fe}\left(\mathrm{SO}_{4}\right)_{2} \cdot 2 \mathrm{H}_{2} \mathrm{O}$ [3], the blödite-type $\mathrm{Na}_{2} \mathrm{Fe}\left(\mathrm{SO}_{4}\right)_{2} \cdot 4 \mathrm{H}_{2} \mathrm{O}$ [4], the alluaudite-type $\mathrm{Na}_{2+2 \mathrm{x}} \mathrm{Fe}_{2-\mathrm{x}}\left(\mathrm{SO}_{4}\right)_{3}$ [5-7], and the eldfellite-type $\mathrm{NaFe}\left(\mathrm{SO}_{4}\right)_{2}[8]$ are active in sodium or lithium ion batteries. The sodium manganese sulfate system was

\footnotetext{
*Corresponding author: Hamdi Ben Yahia, Qatar Environment and Energy Research Institute (QEERI 2.0), Hamad Bin Khalifa University, Qatar Foundation, P.O. Box 34110 Doha, Qatar,

E-mail: Hyahia@qf.org.qa
}

also of interest. Several phases were discovered, such as the vanthoffite-type $\mathrm{Na}_{6} \mathrm{Mn}\left(\mathrm{SO}_{4}\right)_{4}$ [9], the glauberite-type $\mathrm{Na}_{2} \mathrm{Mn}\left(\mathrm{SO}_{4}\right)_{2}$ [10], the alluaudite-type $\mathrm{Na}_{2+2 \mathrm{x}} \mathrm{Mn}_{2-\mathrm{x}}\left(\mathrm{SO}_{4}\right)_{3}$ $[11,12], \mathrm{Na}_{12} \mathrm{Mn}_{7}\left(\mathrm{SO}_{4}\right)_{13} \cdot 15 \mathrm{H}_{2} \mathrm{O}[13], \mathrm{Na}_{2} \mathrm{Mn}_{1.167}\left(\mathrm{SO}_{4}\right)_{2} \mathrm{~S}_{0.33} \mathrm{O}_{1.167}$ - $2 \mathrm{H}_{2} \mathrm{O}$ [10], the kröhnkite-type $\mathrm{Na}_{2} \mathrm{Mn}\left(\mathrm{SO}_{4}\right)_{2} \cdot 2 \mathrm{H}_{2} \mathrm{O}$ [11], the blödite-type $\mathrm{Na}_{2} \mathrm{Mn}\left(\mathrm{SO}_{4}\right)_{2} \cdot 4 \mathrm{H}_{2} \mathrm{O}$ [14] and $\mathrm{Na}_{2} \mathrm{Mn}_{3}\left(\mathrm{SO}_{4}\right)_{4}$ (1) [15]. The latter compound was prepared at low temperature $\left(450{ }^{\circ} \mathrm{C}\right)$ from a stoichiometric mixture of $\mathrm{Na}_{2} \mathrm{SO}_{4}$ and $\mathrm{MnSO}_{4} \cdot \mathrm{H}_{2} \mathrm{O}$. It crystallizes in the space group $\mathrm{Cmc} 2_{1}$ and the unit cell parameters $a 1=14.8307(18), b 1=9.9107(18)$, and $c 1=8.6845(12) \AA$, which can also be transformed to the setting $B b 2_{1} m$ with the unit cell parameters $a 2=9.9107(18)$, $b 2=8.6845(12)$, and $c 2=14.8307(18) \AA$. To differentiate between the unit cell parameters of the $\mathrm{Na}_{2} \mathrm{M}_{3}\left(\mathrm{SO}_{4}\right)_{4}$ compounds $(\mathrm{M}=\mathrm{Mg}$ and $\mathrm{Mn})$, these compounds that were prepared by different methods have been attributed a number (n) and the unit cell parameters $a_{\mathrm{n}}, b_{\mathrm{n}}$, and $c_{\mathrm{n}}$.

During our search for new positive- and negativeelectrodes and solid electrolytes for sodium ion batteries, we have investigated several systems [16-23]. In the binary phase diagram $\mathrm{Na}_{2} \mathrm{SO}_{4}-\mathrm{MgSO}_{4}$, we prepared the compositions $\mathrm{Na}_{2} \mathrm{Mg}\left(\mathrm{SO}_{4}\right)_{2}$ and $\mathrm{Na}_{2} \mathrm{Mg}_{2}\left(\mathrm{SO}_{4}\right)_{3}$. Interestingly, during the crystallization of $\mathrm{Na}_{2} \mathrm{Mg}_{2}\left(\mathrm{SO}_{4}\right)_{3}$ at $800{ }^{\circ} \mathrm{C}$ single crystals of $\mathrm{Na}_{2} \mathrm{Mg}_{3}\left(\mathrm{SO}_{4}\right)_{4}$ (3) were isolated. This compound crystallizes in the space group $P b c a$ with the unit cell parameters $a 3=9.5498(4), b 3=8.7198(3)$ and $c 3=29.2460(11) \AA$. One can clearly notice that $a 3, b 3$ and $c 3$ are similar to $a 2, b 2$ and $2 \times c 2$, respectively. This is clearly a hint on the possible existence of polymorphic modifications in these compounds. Therefore, we decided to replace gradually $\mathrm{Mg}$ by $\mathrm{Mn}$ in order to prepare the $\mathrm{Pbca}$-polymorph of $\mathrm{Na}_{2} \mathrm{Mn}_{3}\left(\mathrm{SO}_{4}\right)_{4}$ which might be of interest as a positive electrode for sodium ion batteries. During the crystallization of the compounds $\mathrm{Na}_{2} \mathrm{Mg}_{2} \mathrm{Mn}\left(\mathrm{SO}_{4}\right)_{4}, \mathrm{Na}_{2} \mathrm{MgMn}_{2}\left(\mathrm{SO}_{4}\right)_{4}$ and $\mathrm{Na}_{2} \mathrm{Mn}_{3}\left(\mathrm{SO}_{4}\right)_{4}$ at $800{ }^{\circ} \mathrm{C}$, single crystals of $\mathrm{Pbca}$ $\mathrm{Na}_{2} \mathrm{Mg}_{2.5} \mathrm{Mn}_{0.5}\left(\mathrm{SO}_{4}\right)_{4}$ (4), Pbca- $\mathrm{Na}_{2} \mathrm{Mg}_{1.5} \mathrm{Mn}_{1.5}\left(\mathrm{SO}_{4}\right)_{4}$ (5) and Pbca- $\mathrm{Na}_{2} \mathrm{Mn}_{3}\left(\mathrm{SO}_{4}\right)_{4}$ (6) were isolated, respectively. Their crystal structures and compositions were determined from single crystal X-ray diffraction data. The three compounds are isostructural with $\mathrm{Pbca}-\mathrm{Na}_{2} \mathrm{Mg}_{3}\left(\mathrm{SO}_{4}\right)_{4}$ (3). Their unit cell parameters are given in the Tables S1 and S2.

Since we realized that Dr. Slater had already published the crystal structure of $\mathrm{Na}_{2} \mathrm{Mg}_{3}\left(\mathrm{SO}_{4}\right)_{4}$ (7) [24], herein we report on mainly the crystal structure of the new polymorph $\mathrm{Pbca}-\mathrm{Na}_{2} \mathrm{Mn}_{3}\left(\mathrm{SO}_{4}\right)_{4}$ (6) based on single 
crystals X-ray diffraction data. Furthermore, we discuss its structural relationship with the known polymorph Cmc $2_{1}-\mathrm{Na}_{2} \mathrm{Mn}_{3}\left(\mathrm{SO}_{4}\right)_{4}$ using complex group-subgroup schemes in the Bärnighausen formalism.

\section{Experimental section}

\section{Synthesis}

The title compound $\mathrm{Pbca}-\mathrm{Na}_{2} \mathrm{Mn}_{3}\left(\mathrm{SO}_{4}\right)_{4}$ was prepared by a solid state reaction route, from a stoichiometric mixture of $\mathrm{Na}_{2} \mathrm{SO}_{4}$ (Aldrich, 99.5\%) and $\mathrm{MnSO}_{4} \cdot \mathrm{H}_{2} \mathrm{O}$ (Merck, 99.9\%). $0.298 \mathrm{~g}$ and $1.046 \mathrm{~g}$ of the starting materials, respectively were ground in an agate mortar then pelletized and put into platinum crucible and heated at $600{ }^{\circ} \mathrm{C}$ for $12 \mathrm{~h}$ in Argon. The progress of the reaction was followed by powder $\mathrm{X}$-ray diffraction (PXRD) and the beige powder sample was pure. The single crystals were then obtained using self-flux method. A stoichiometric mixture of $\mathrm{Na}_{2} \mathrm{SO}_{4}$ and $\mathrm{MnSO}_{4} \cdot \mathrm{H}_{2} \mathrm{O}$ was heated at $800{ }^{\circ} \mathrm{C}$ for $12 \mathrm{~h}$ then quenched to room temperature. This led mainly to colourless crystals of $\mathrm{Pbca}-\mathrm{Na}_{2} \mathrm{Mn}_{3}\left(\mathrm{SO}_{4}\right)_{4}$ besides few crystals of $\mathrm{Na}_{2} \mathrm{SO}_{4}$.

The compositions $\mathrm{Na}_{2} \mathrm{Mg}_{2} \mathrm{Mn}\left(\mathrm{SO}_{4}\right)_{4}$ and $\mathrm{Na}_{2} \mathrm{MgMn}_{2}\left(\mathrm{SO}_{4}\right)_{4}$ were prepared by a solid state reaction route, from a stoichiometric mixture of $\mathrm{Na}_{2} \mathrm{SO}_{4}$ (Aldrich, 99.5\%), $\mathrm{MgSO}_{4}$ (Merck, 99.9\%) and $\mathrm{MnSO}_{4} \cdot \mathrm{H}_{2} \mathrm{O}$ (Merck, 99.9\%). The two samples were heated at $600{ }^{\circ} \mathrm{C}$ for $12 \mathrm{~h}$ and at $800^{\circ} \mathrm{C}$ for $10 \mathrm{~h}$ in Argon. This led to the formation of Pbca- $\mathrm{Na}_{2} \mathrm{Mg}_{2.5} \mathrm{Mn}_{0.5}\left(\mathrm{SO}_{4}\right)_{4}$ (4) and Pbca- $\mathrm{Na}_{2} \mathrm{Mg}_{1.5} \mathrm{Mn}_{1.5}\left(\mathrm{SO}_{4}\right)_{4}$ (5) single crystals, respectively.

\section{Powder X-ray diffraction measurements}

To ensure the purity of $\mathrm{Pbca}-\mathrm{Na}_{2} \mathrm{Mn}_{3}\left(\mathrm{SO}_{4}\right)_{4}$ powder, routine PXRD measurements were performed. The data were collected at room temperature over the $2 \theta$ angle range of $5^{\circ} \leq 2 \theta \leq 75^{\circ}$ with a step size of $0.01^{\circ}$ using a Bruker D8 advance diffractometer operating with $\mathrm{CuK \alpha}$ radiation (Bruker, Darmstadt, Germany). Full pattern matching refinement was performed with the Jana2006 program package (Institute of Physics, Prague, Czech Republic) [25]. The background was estimated by a Legendre function and the peak shapes were described by a pseudo-Voigt function.

\section{Single crystal X-ray diffraction measurements}

Pbca- $\mathrm{Na}_{2} \mathrm{Mn}_{3}\left(\mathrm{SO}_{4}\right)_{4}$ (6), Pbca- $\mathrm{Na}_{2} \mathrm{Mg}_{2.5} \mathrm{Mn}_{0.5}\left(\mathrm{SO}_{4}\right)_{4}$ (4) and Pbca$\mathrm{Na}_{2} \mathrm{Mg}_{1.5} \mathrm{Mn}_{1.5}\left(\mathrm{SO}_{4}\right)_{4}$ (5) single crystals suitable for single crystal X-ray diffraction were selected on the basis of the size and the sharpness of the diffraction spots. The data collections were carried out on a Bruker D8 Venture diffractometer using MoK $\alpha$ radiation. Data processing and all refinements were performed with the APEX3 and JANA2006 program packages, respectively $[25,26]$. For the data collection details, see Tables 1 and S1. Further details on the structure refinements of $\mathrm{Na}_{2} \mathrm{Mn}_{3}\left(\mathrm{SO}_{4}\right)_{4}, \mathrm{Na}_{2} \mathrm{Mg}_{1.5} \mathrm{Mn}_{1.5}\left(\mathrm{SO}_{4}\right)_{4}, \mathrm{Na}_{2} \mathrm{Mg}_{2.5} \mathrm{Mn}_{0.5}\left(\mathrm{SO}_{4}\right)_{4}$, and $\mathrm{Na}_{2} \mathrm{Mg}_{3}\left(\mathrm{SO}_{4}\right)_{4}$ may be obtained from the Fachinformationszentrum Karlsruhe, D-76344 Eggenstein-Leopoldshafen (Germany), by quoting the Registry No. CSD-1936610-1936613.
Tab. 1: Crystallographic data and structure refinement for Pbca- $\mathrm{Na}_{2} \mathrm{Mn}_{3}\left(\mathrm{SO}_{4}\right)_{4}$.

\begin{tabular}{|c|c|}
\hline \multicolumn{2}{|l|}{ Crystal data } \\
\hline Chemical formula & $\mathrm{Na}_{2} \mathrm{Mn}_{3}\left(\mathrm{SO}_{4}\right)_{4}$ \\
\hline$M_{\mathrm{r}}$ & 595 \\
\hline Crystal system & Orthorhombic \\
\hline Space group & Pbca \\
\hline Temperature (K) & 293 \\
\hline$a, b, c(\AA)$ & $9.8313(4), 8.7467(3), 29.6004(11)$ \\
\hline$V\left(\AA^{3}\right)$ & $2545.38(17)$ \\
\hline$Z$ & 8 \\
\hline Radiation type & Mo $K \alpha$ \\
\hline$\mu\left(\mathrm{mm}^{-1}\right)$ & 3.75 \\
\hline Crystal size $(\mathrm{mm})$ & $0.47 \times 0.08 \times 0.04$ \\
\hline \multicolumn{2}{|l|}{ Data collection } \\
\hline Diffractometer & D8 Venture \\
\hline Absorption correction & Multi-scan \\
\hline \multicolumn{2}{|l|}{$S A D A B S$} \\
\hline$T_{\min }, T_{\max }$ & $0.593,0.747$ \\
\hline No. of measured reflections & 18,976 \\
\hline No. of independent reflections & 3151 \\
\hline No. of observed reflections & $2605[I>2 \sigma(I)]$ \\
\hline$R_{\text {int }}$ & 0.033 \\
\hline$(\sin \theta / \lambda)_{\max }\left(\AA^{-1}\right)$ & 0.666 \\
\hline \multicolumn{2}{|l|}{ Refinement } \\
\hline$R\left[F^{2}>2 \sigma\left(F^{2}\right)\right], w R\left(F^{2}\right), S$ & $0.025,0.065,1.14$ \\
\hline No. of reflections & 3151 \\
\hline No. of parameters & 227 \\
\hline No. of restraints & 0 \\
\hline$\Delta \rho_{\max }, \Delta \rho_{\min }\left(\mathrm{e} \AA^{-3}\right)$ & $0.38,-0.31$ \\
\hline
\end{tabular}

\section{Electron microprobe analysis}

Semiquantitative energy-dispersive X-ray spectroscopy (EDX) analyses of different single crystals including the ones investigated on the diffractometer were carried out with a 7610F (JEOL) scanning electron microscope (SEM). Although the crystals were beam sensitive, the experimentally observed compositions were close to the ideal one of $\mathrm{Na}_{2} \mathrm{Mn}_{3}\left(\mathrm{SO}_{4}\right)_{4}$.

\section{Results and discussion}

\section{Structure refinement}

The systematic absences observed for $\mathrm{Na}_{2} \mathrm{Mn}_{3}\left(\mathrm{SO}_{4}\right)_{4}$ agree with the $\mathrm{Pbca}$ space group. Atomic positions of the majority of atoms were found by the Superflip program implemented in JANA2006 program package $[25,27]$. The use of the difference Fourier synthesis allowed us to localize the remaining oxygen atomic positions. With anisotropic atomic displacement parameters (ADPs), the final residual factors converged 
to the values $R(F)=0.025$ and $w R\left(F^{2}\right)=0.0650$ for 227 refined parameters, 3151 independent reflections and difference-Fourier residues in the range between -0.38 and $+0.31 \mathrm{e}^{-3}$. The refined atomic positions and ADPs are given in Tables 2 and S3, respectively. The EDX elemental analyses performed on the crystal used for the data collection confirmed the composition $\mathrm{Na}_{2} \mathrm{Mn}_{3}\left(\mathrm{SO}_{4}\right)_{4}$ (Figure 1). Furthermore, using the crystallographic data obtained by the single crystal XRD, the X-ray powder pattern of $\mathrm{Na}_{2} \mathrm{Mn}_{3}\left(\mathrm{SO}_{4}\right)_{4}$ (8) could be fully indexed which confirmed the formation of this sample (Figure 2). The refined unit cell parameters were $a_{8}=9.9111(3), b_{8}=8.7065(3)$, and $c_{8}=29.6932(10) \AA$. One should mention that it is not excluded that this sample could be a mixture of both polymorphs.

The crystal structures of $P b c a-\mathrm{Na}_{2} \mathrm{Mg}_{2.5} \mathrm{Mn}_{0.5}\left(\mathrm{SO}_{4}\right)_{4}$ (4) and $P b c a-\mathrm{Na}_{2} \mathrm{Mg}_{1.5} \mathrm{Mn}_{1.5}\left(\mathrm{SO}_{4}\right)_{4}$ (5) were refined using the same procedure as for $\mathrm{Pbca}-\mathrm{Na}_{2} \mathrm{Mn}_{3}\left(\mathrm{SO}_{4}\right)_{4}$ (6). The refinement of the occupancies of the manganese atoms showed a significant decrease consequently, $\mathrm{Mn} / \mathrm{Mg}$ statistical disorders were introduced and restrictions on their ADPs were applied. The refined atomic positions and ADPs are given in Tables S4 and S5, respectively.

Tab. 2: Fractional atom coordinates and isotropic atomic displacement parameters $\left(\AA^{2}\right)$ for $\mathrm{Pbca}-\mathrm{Na}_{2} \mathrm{Mn}_{3}\left(\mathrm{SO}_{4}\right)_{4}$.

\begin{tabular}{llrrrr}
\hline Atom & Wyck. & $\boldsymbol{x}$ & $\boldsymbol{y}$ & $\boldsymbol{z}$ & $\boldsymbol{U e q}\left(\AA^{2}\right)$ \\
\hline $\mathrm{Na} 1$ & $8 c$ & $0.45388(10)$ & $-0.12394(11)$ & $0.69154(3)$ & $0.0211(3)$ \\
$\mathrm{Na2}$ & $8 c$ & $0.40639(12)$ & $0.92439(12)$ & $0.55287(4)$ & $0.0315(4)$ \\
Mn1 & $8 c$ & $0.85011(3)$ & $-0.07081(4)$ & $0.69589(1)$ & $0.01166(11)$ \\
Mn2 & $8 c$ & $0.68455(4)$ & $0.43074(4)$ & $0.55205(1)$ & $0.01420(11)$ \\
Mn3 & $8 c$ & $0.32662(4)$ & $0.25433(4)$ & $0.62627(1)$ & $0.01423(11)$ \\
$\mathrm{S} 1$ & $8 c$ & $0.36779(5)$ & $0.22999(6)$ & $0.73526(2)$ & $0.00833(15)$ \\
01 & $8 c$ & $0.31892(16)$ & $0.30762(19)$ & $0.77584(5)$ & $0.0158(5)$ \\
02 & $8 c$ & $0.50865(16)$ & $0.27808(19)$ & $0.72723(6)$ & $0.0179(5)$ \\
03 & $8 c$ & $0.36487(16)$ & $0.06367(17)$ & $0.74200(5)$ & $0.0147(5)$ \\
04 & $8 c$ & $0.28144(16)$ & $0.27024(19)$ & $0.69614(5)$ & $0.0158(5)$ \\
$\mathrm{S} 2$ & $8 c$ & $0.44398(5)$ & $0.59764(6)$ & $0.62045(2)$ & $0.00955(15)$ \\
05 & $8 c$ & $0.50687(17)$ & $0.58284(19)$ & $0.66480(5)$ & $0.0205(5)$ \\
06 & $8 c$ & $0.32541(17)$ & $0.4938(2)$ & $0.61729(6)$ & $0.0207(6)$ \\
07 & $8 c$ & $0.38987(17)$ & $0.75595(17)$ & $0.61640(5)$ & $0.0142(5)$ \\
08 & $8 c$ & $0.53850(17)$ & $0.56973(19)$ & $0.58405(6)$ & $0.0234(6)$ \\
S3 & $8 c$ & $0.61905(6)$ & $0.12227(6)$ & $0.62812(2)$ & $0.00922(15)$ \\
09 & $8 c$ & $0.6340(2)$ & $0.29033(19)$ & $0.62759(6)$ & $0.0261(6)$ \\
010 & $8 c$ & $0.65967(17)$ & $0.0609(2)$ & $0.58450(6)$ & $0.0246(6)$ \\
011 & $8 c$ & $0.69495(18)$ & $0.0558(2)$ & $0.66506(6)$ & $0.0249(6)$ \\
012 & $8 c$ & $0.47360(16)$ & $0.0860(2)$ & $0.63575(6)$ & $0.0205(5)$ \\
S4 & $8 c$ & $0.39288(6)$ & $0.27110(6)$ & $0.51362(2)$ & $0.00971(15)$ \\
013 & $8 c$ & $0.31187(16)$ & $0.40863(18)$ & $0.50557(6)$ & $0.0177(5)$ \\
014 & $8 c$ & $0.37040(16)$ & $0.15742(18)$ & $0.47753(5)$ & $0.0168(5)$ \\
015 & $8 c$ & $0.53949(16)$ & $0.30299(18)$ & $0.51469(5)$ & $0.0184(5)$ \\
016 & $8 c$ & $0.34954(18)$ & $0.2017(2)$ & $0.55640(5)$ & $0.0211(5)$ \\
\hline & & & & &
\end{tabular}

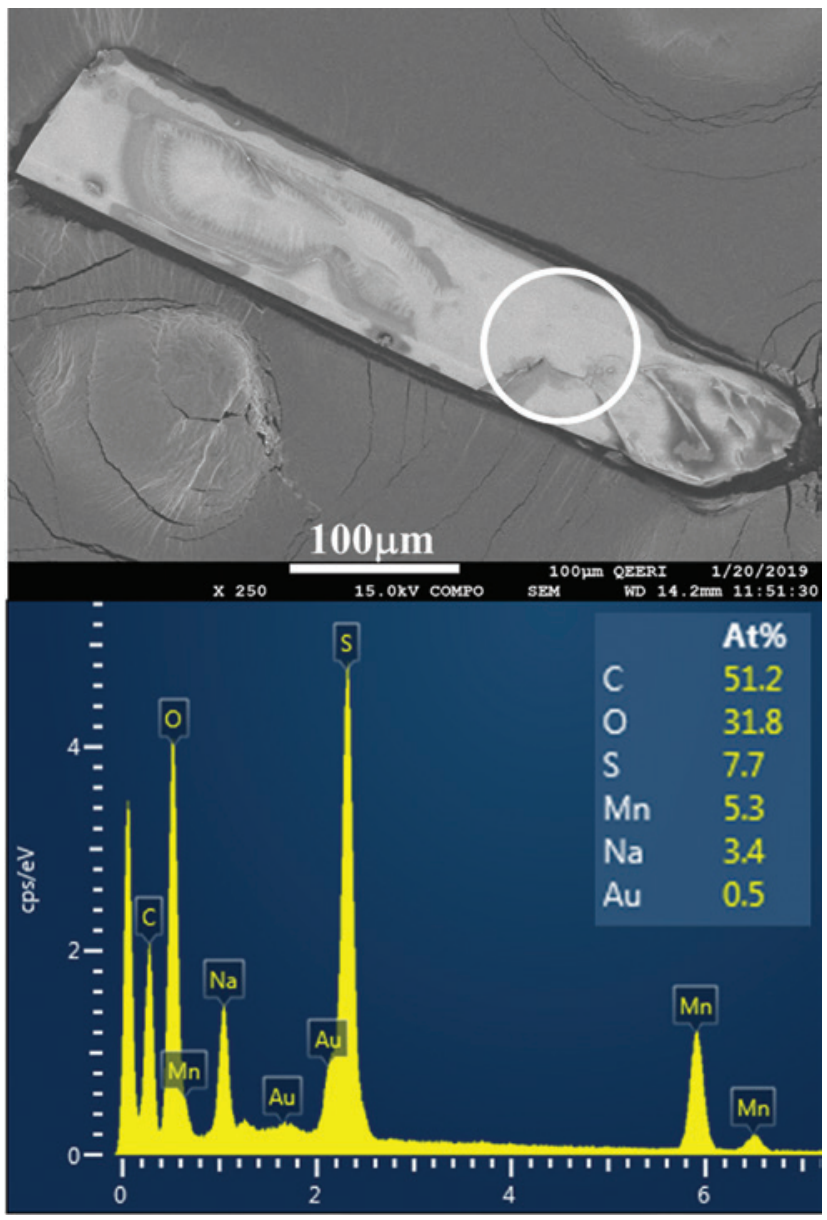

Fig. 1: Image and EDX analysis of the $\mathrm{Na}_{2} \mathrm{Mn}_{3}\left(\mathrm{SO}_{4}\right)_{4}$ single crystal used for the data collection. The circle represents the area where the EDX analysis was performed.

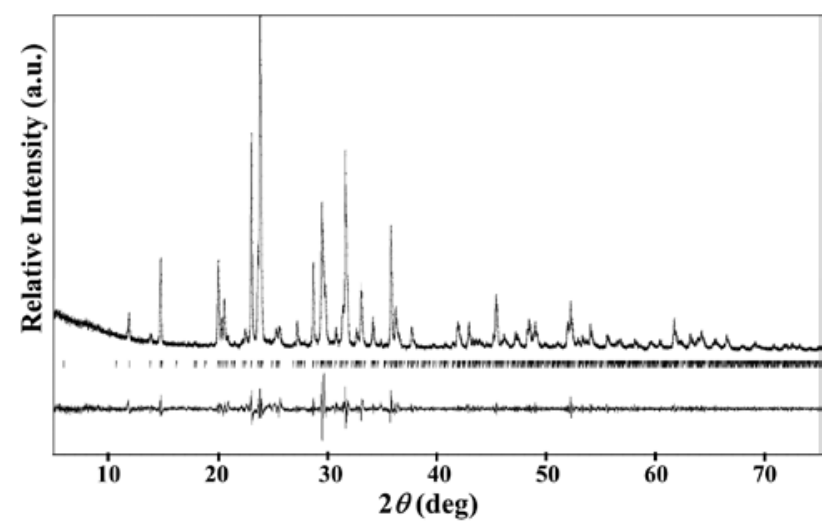

Fig. 2: Observed, calculated and difference plots for PXRD (CU- $\mathrm{K}_{\alpha}$ radiation) refinement of $\mathrm{Pbca}-\mathrm{Na}_{2} \mathrm{Mn}_{3}\left(\mathrm{SO}_{4}\right)_{4}$.

\section{Crystal structure}

Pbca- $\mathrm{Na}_{2} \mathrm{Mn}_{3}\left(\mathrm{SO}_{4}\right)_{4}(6)$ is a new polymorph of $\mathrm{Na}_{2} \mathrm{Mn}_{3}\left(\mathrm{SO}_{4}\right)_{4}$. Its structure contains a buildup of $\mathrm{Mn}_{2} \mathrm{O}_{11}$ dimer units and 
$\mathrm{MnO}_{5}$ trigonal pyramids. The latter ones are interconnected by sharing corners with the $\mathrm{SO}_{4}$ tetrahedra leaving cavities in which two symmetry different sodium atoms are located (Figure 3a). Selected interatomic distances are given in Table 3.

In $\mathrm{Pbca}-\mathrm{Na}_{2} \mathrm{Mn}_{3}\left(\mathrm{SO}_{4}\right)_{4}$, the manganese atoms occupy three different atomic positions. Mn1 and Mn2 are coordinated by six oxygen atoms forming strongly distorted octahedra that share a corner and form a $\mathrm{Mn}_{2} \mathrm{O}_{11}$ dimer unit (Figure 4a) with Mn1-O distances ranging from 2.0945(18) to 2.3635(17) $\AA$ and Mn2-O distances ranging from 2.1063(17) to 2.5991(17) A (Table 3). Mn3 is coordinated by five oxygen atoms forming a trigonal bipyramid with the Mn3-O distances ranging from 2.0818(17) to 2.1484(17) $\AA$ (Figure 4c). The average distances of 2.1783 and $2.2238 \AA$ for Mn1-O and Mn2-O, respectively are in good agreement with the sum of the effective ionic radii of the high spin $\mathrm{Mn}^{2+}$ and $\mathrm{O}^{2-}\left\{\mathrm{IR}_{(\mathrm{Mn} 2+)}+\mathrm{IR}_{(02-)}=0.83+1.4 \AA\right.$ [ [29]. The $\mathrm{Mn}_{2} \mathrm{O}_{11}$ dimer units and the $\mathrm{MnO}_{5}$ trigonal bipyramids are interconnected through four different $\mathrm{SO}_{4}$ tetrahedra. In the $\mathrm{S}_{4} \mathrm{O}_{4}$ and $\mathrm{S}_{4} \mathrm{O}_{4}$ tetrahedra the $\mathrm{S}-\mathrm{O}$ distances are very similar, whereas in the $\mathrm{S}_{2} \mathrm{O}_{4}$ and $\mathrm{S}_{3} \mathrm{O}_{4}$ tetrahedra short and stretched $\mathrm{S}-\mathrm{O}$ distances are observed (see Table 3 ). The distances $\mathrm{d}(\mathrm{S}-\mathrm{O})_{\min }$ and $\mathrm{d}(\mathrm{S}-\mathrm{O})_{\max }$ of $1.4436(18)$ and $1.4882(16) \AA$, respectively are slightly shorter than the sum of the effective ionic radii of $\mathrm{S}^{6+}$ and $\mathrm{O}^{2-}\left\{\mathrm{IR}_{(\mathrm{S} 6+)}+\mathrm{IR}_{(02-)}=0.12+1.38 \AA\right.$ $\}$ [29].

The title compound contains two different sodium atoms $\mathrm{Na} 1$ and $\mathrm{Na} 2 . \mathrm{Na} 1$ is coordinated by seven oxygen atoms forming a strongly distorted capped-trigonalprism with Na1-O distances ranging from 2.3853(18) to 2.7341(19) A and with an average Na1-O distance of $2.531 \AA$ and a bond valence sums (BVS) of 1.01 (Figure 4e). For Na2 the coordination sphere is not well defined. Even when the coordination sphere is increased to $3.2 \AA$, Na2 remains underbonded with a BVS of 0.9. The BVS values of 2.15, 2.02, 2.06, 6.09, 6.12, 6.16 and 6.09 are in agreement with the expected value of +2 and +6 for $\mathrm{Mn}^{+2}, \mathrm{Mn}^{+2}, \mathrm{Mn}^{+2}$, $\mathrm{S}^{+6}, \mathrm{~S}^{+6}, \mathrm{~S}^{+6}$ and $\mathrm{S} 4^{+6}$, respectively [28].

\section{Comparison of $\mathrm{Pbca}-\mathrm{Na}_{2} \mathrm{Mn}_{3}\left(\mathrm{SO}_{4}\right)_{4}$ and $B b 2{ }_{1} m-\mathrm{Na}_{2} \mathrm{Mn}_{3}\left(\mathrm{SO}_{4}\right)_{4}$}

The crystal structures of $\mathrm{Pbca}-\mathrm{Na}_{2} \mathrm{Mn}_{3}\left(\mathrm{SO}_{4}\right)_{4}$ and $B b 2_{1} m-\mathrm{Na}_{2} \mathrm{Mn}_{3}\left(\mathrm{SO}_{4}\right)_{4}$ are given in Figures $3 \mathrm{a}$ and $\mathrm{b}$, respectively. Although both structures are different, one observes common features that can be listed below:

1. In $\mathrm{Pbca}-\mathrm{Na}_{2} \mathrm{Mn}_{3}\left(\mathrm{SO}_{4}\right)_{4}$ the cell parameters $a 6, b 6$ and $c 6$ are almost equal to $a 2, b 2$ and $2 \times c 2$ in $B b 2_{1} m-\mathrm{Na}_{2} \mathrm{Mn}_{3}\left(\mathrm{SO}_{4}\right)_{4}$, respectively (Figure 3),

2. $\mathrm{Mn}_{2} \mathrm{O}_{11}$ dimer units are present in both compounds. Only a slight difference in the interatomic distances is observed (Figures $4 \mathrm{a}$ and $\mathrm{b}$ ),

3. $\mathrm{MnO}_{5}$ trigonal-bipyramids are present in both compounds (Figures $4 \mathrm{c}$ and d). If we consider the stretched distances $\mathrm{d}_{\mathrm{Mn} 3-06}$ in $\mathrm{Pbca}-\mathrm{Na}_{2} \mathrm{Mn}_{3}\left(\mathrm{SO}_{4}\right)_{4}$ and $\mathrm{d}_{\mathrm{Mn} 2-\mathrm{O} 8}$ in $\mathrm{Bb2}{ }_{1} \mathrm{~m}-\mathrm{Na}_{2} \mathrm{Mn}_{3}\left(\mathrm{SO}_{4}\right)_{4}$, the isolated trigonal-bipyramids would be transformed to an infinite chain of cornersharing octahedra,

4. The $\mathrm{Mn}_{2} \mathrm{O}_{11}$ dimer units and the $\mathrm{MnO}_{5}$ trigonal bipyramids are interconnected through $\mathrm{SO}_{4}$ tetrahedra which are slightly tilted in $\mathrm{Pbca}-\mathrm{Na}_{2} \mathrm{Mn}_{3}\left(\mathrm{SO}_{4}\right)_{4}$ in comparison to the tetrahedra in $B b 2_{1} m-\mathrm{Na}_{2} \mathrm{Mn}_{3}\left(\mathrm{SO}_{4}\right)_{4}$ (Figure 5),

5. The coordination of $\mathrm{Na} 1$ in both compounds is similar (Figures 4e and f), and

6. The theoretical powder X-ray diffraction patterns are similar (Figure S1). Only few additional peaks were observed for $\mathrm{Pbca}-\mathrm{Na}_{2} \mathrm{Mn}_{3}\left(\mathrm{SO}_{4}\right)_{4}$.
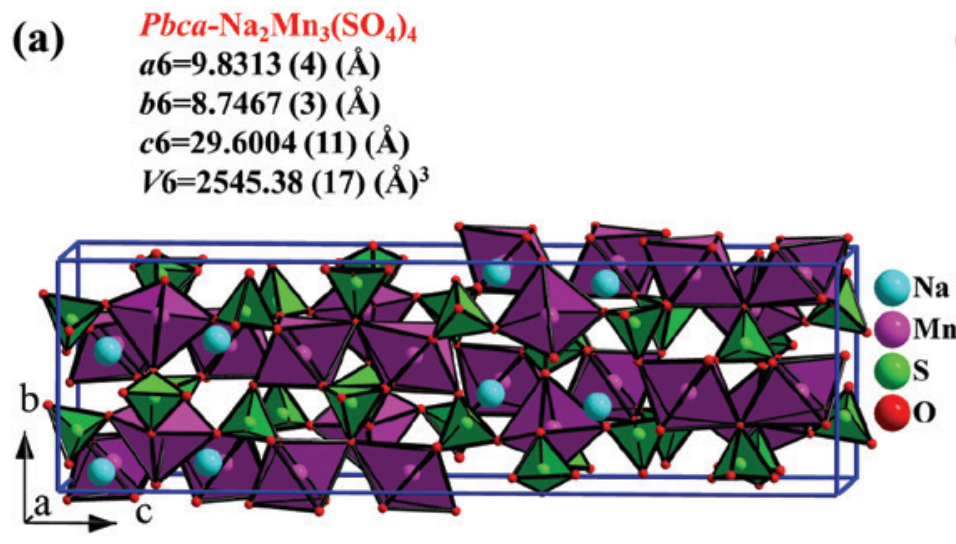

(b)
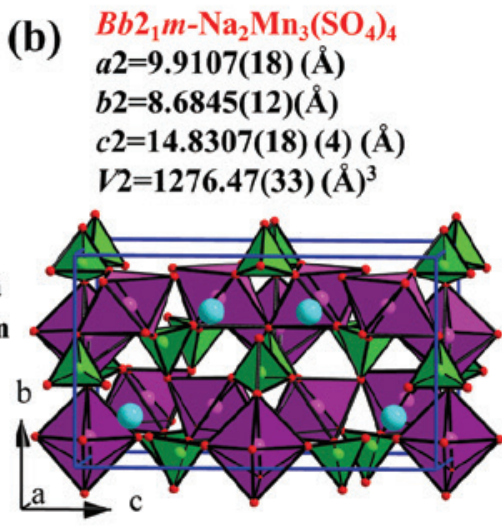

Fig. 3: Perspective view of the crystal structures of $\mathrm{Pbca}-\mathrm{Na}_{2} \mathrm{Mn}_{3}\left(\mathrm{SO}_{4}\right)_{4}(\mathrm{a})$ and $\mathrm{Bb}{ }_{1} \mathrm{~m}-\mathrm{Na}_{2} \mathrm{Mn}_{3}\left(\mathrm{SO}_{4}\right)_{4}$ (b). Only the polyhedra arround the $\mathrm{Mn}$ and $\mathrm{S}$ atoms were drawn. 
Tab. 3: Interatomic distances (in $\AA$ ) and bond valence sums (BVS) for $\mathrm{Pbca}-\mathrm{Na}_{2} \mathrm{Mn}_{3}\left(\mathrm{SO}_{4}\right)_{4}$ and $B b 2_{1} m-\mathrm{Na}_{2} \mathrm{Mn}_{3}\left(\mathrm{SO}_{4}\right)_{4}$.

\begin{tabular}{|c|c|c|c|c|c|}
\hline \multicolumn{4}{|c|}{$\mathrm{Pbca}-\mathrm{Na}_{2} \mathrm{Mn}_{3}\left(\mathrm{SO}_{4}\right)_{4}$} & \multicolumn{2}{|c|}{$\mathrm{Bb2}_{1} \mathrm{~m}-\mathrm{Na}_{2} \mathrm{Mn}_{3}\left(\mathrm{SO}_{4}\right)_{4}$} \\
\hline & Distances & & Distances & & Distances \\
\hline $\mathrm{Na} 1-03$ & $2.3853(18)$ & Mn1-011 & $2.0945(18)$ & Na1-010 & $2.283(4)$ \\
\hline $\mathrm{Na} 1-012$ & $2.478(2)$ & $\mathrm{Mn} 1-02$ & $2.1297(17)$ & $\mathrm{Na} 1-07$ & $2.330(3)$ \\
\hline $\mathrm{Na} 1-04$ & $2.4955(19)$ & Mn1-01 & $2.1431(16)$ & Na1-09 & $2.415(4)$ \\
\hline $\mathrm{Na1}-01$ & $2.5060(18)$ & Mn1-05 & $2.1517(17)$ & $\mathrm{Na1}-01$ & $2.619(4)$ \\
\hline $\mathrm{Na} 1-07$ & $2.5390(18)$ & $\mathrm{Mn} 1-03$ & $2.1874(16)$ & $\mathrm{Na} 1-05$ & $2.637(4)$ \\
\hline $\mathrm{Na} 1-02$ & $2.5790(19)$ & Mn1-09 & $2.3635(17)$ & $\mathrm{Na} 1-03$ & $2.650(4)$ \\
\hline \multirow[t]{3}{*}{$\mathrm{Na} 1-05$} & 2.7341(19) & & $<2.1783>$ & & $<2.489>$ \\
\hline & $<2.531>$ & & a $2.154(4)[6]$ & & $1.022[6]$ \\
\hline & a1.013(2) [7] & $\mathrm{Mn} 2-08$ & $2.1063(17)$ & Mn1-04 & $2.095(3)$ \\
\hline $\mathrm{Na} 2-07$ & $2.3944(18)$ & $M n 2-015$ & $2.1226(16)$ & Mn1-09 & $2.096(3)$ \\
\hline $\mathrm{Na2}-014$ & $2.4774(19)$ & Mn2-010 & $2.1364(18)$ & $\mathrm{Mn} 1-05$ & 2.161(3) \\
\hline $\mathrm{Na} 2-016$ & $2.492(2)$ & $M n 2-014$ & $2.1679(16)$ & Mn1-01 & 2.171(3) \\
\hline $\mathrm{Na} 2-013$ & $2.5658(19)$ & $M n 2-013$ & $2.2102(17)$ & Mn1-010 & $2.216(3)$ \\
\hline $\mathrm{Na2}-015$ & $2.8703(19)$ & Mn2-09 & 2.5991(17) & Mn1-06 & $2.408(2)$ \\
\hline $\mathrm{Na2}-012$ & $2.907(2)$ & & $<2.2238>$ & & $<2.1911>$ \\
\hline $\mathrm{Na} 2-010$ & $2.916(2)$ & & a $2.018(4)[6]$ & & a $2.103(8)[6]$ \\
\hline $\mathrm{Na} 2-06$ & $3.033(2)$ & Mn3-012 & $2.0818(17)$ & $\mathrm{Mn} 2-\mathrm{O} 2$ & $2.082(4)$ \\
\hline $\mathrm{Na2}-014$ & $3.0420(19)$ & Mn3-06 & $2.1113(18)$ & $\mathrm{Mn} 2-03(\times 2)$ & $2.123(3)$ \\
\hline \multirow[t]{4}{*}{$\mathrm{Na} 2-016$} & $3.183(2)$ & $\mathrm{Mn3}-04$ & $2.1198(15)$ & $\mathrm{Mn} 2-08$ & $2.161(5)$ \\
\hline & $<2.788>$ & Mn3-016 & $2.1309(16)$ & $\mathrm{Mn} 2-07$ & $2.174(4)$ \\
\hline & ${ }^{\mathrm{a}} 0.8975(18)[10]$ & Mn3-07 & $2.1484(17)$ & $\mathrm{Mn} 2-08$ & $2.557(5)$ \\
\hline & & & $<2.1184>$ & & $<2.1326>$ \\
\hline S1-01 & $1.4611(16)$ & & ${ }^{\mathrm{a}} 2.062(4)[5]$ & & ${ }^{\mathrm{a}} 1.988(10)[5]$ \\
\hline $\mathrm{S} 1-02$ & $1.4667(17)$ & S3-011 & $1.4456(19)$ & & \\
\hline $\mathrm{S} 1-03$ & $1.4687(16)$ & S3-010 & $1.4543(19)$ & & \\
\hline \multirow[t]{3}{*}{ S1-04 } & $1.4782(16)$ & S3-09 & $1.4773(18)$ & & \\
\hline & $<1.4686>$ & S3-012 & $1.4819(17)$ & & \\
\hline & ${ }^{\mathrm{a}} 6.087(13)[4]$ & & $<1.4648>$ & & \\
\hline S2-08 & $1.4436(18)$ & & ${ }^{\mathrm{a}} 6.156(15)[4]$ & & \\
\hline S2-05 & $1.4569(17)$ & S4-013 & $1.4622(17)$ & & \\
\hline S2-06 & $1.4808(18)$ & S4-016 & $1.4673(17)$ & & \\
\hline \multirow[t]{4}{*}{$\mathrm{S} 2-07$} & $1.4882(16)$ & S4-015 & $1.4684(16)$ & & \\
\hline & $<1.4674>$ & S4-014 & $1.4761(16)$ & & \\
\hline & ${ }^{\mathrm{a}} 6.115(14)[4]$ & & $<1.4685>$ & & \\
\hline & & & ${ }^{\mathrm{a}} 6.090(14)[4]$ & & \\
\hline
\end{tabular}

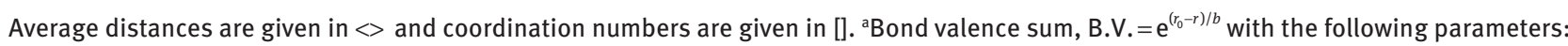
$b=0.37, r_{0}\left(\mathrm{Na}^{\prime}-0\right)=1.803, r_{0}\left(\mathrm{Mn}^{\prime \prime}-0\right)=1.790$, and $r_{0}\left(\mathrm{~S}^{\mathrm{VI}}-0\right)=1.624 \AA$ [28].

All the similarities mentioned above indicate that there is a strong structural relationship between both polymorphs. For an accurate comparison of $B b 2_{1} m-\mathrm{Na}_{2} \mathrm{Mn}_{3}\left(\mathrm{SO}_{4}\right)_{4} \quad[a 2=9.9107(18), \quad b 2=8.6845(12)$, and $\quad c 2=14.8307(18) \quad \AA]$ and $P b c a-\mathrm{Na}_{2} \mathrm{Mn}_{3}\left(\mathrm{SO}_{4}\right)_{4}$ $[a 6=9.8313(4), b 6=8.7467(3)$ and $c 6=29.6004(11) \AA]$, it is necessary to find a supercell, common to both structures, in which the comparison of the atomic position would be simple. For this purpose, the use of groupsubgroup schemes in the Bärnighausen formalism is the key [30-32]. After different transformations, the $\mathrm{Pbca}-\mathrm{Na}_{2} \mathrm{Mn}_{3}\left(\mathrm{SO}_{4}\right)_{4}$ and $\mathrm{Bb} 2_{1} m-\mathrm{Na}_{2} \mathrm{Mn}_{3}\left(\mathrm{SO}_{4}\right)_{4}$ cells were transformed to the new supercells (SC-I) and (SC-II), respectively, which are depicted in Figures 6a and $b$. The unit cell of $\mathrm{Pbca}-\mathrm{Na}_{2} \mathrm{Mn}_{3}\left(\mathrm{SO}_{4}\right)_{4}$ and (SC-I) are identical whereas, the supercell (SC-II) was obtained by doubling the $\mathrm{Bb}_{1} \mathrm{~m}-\mathrm{Na}_{2} \mathrm{Mn}_{3}\left(\mathrm{SO}_{4}\right)_{4}$ unit cell along the $c$ axis. Detailes on these transformations are given in Supplementary Information.

The software Compstru from Bilbao Crystallographic Server (Bilbao, Spain) is often used to compare crystal structures of the same symmetry, however it failed to compare SC-I and SC-II which indicates that the atomic positions in both structures are different. To confirm that, each supercell was divided into five sections parallel to the $c$ axis. The supercell SC-I can be described 


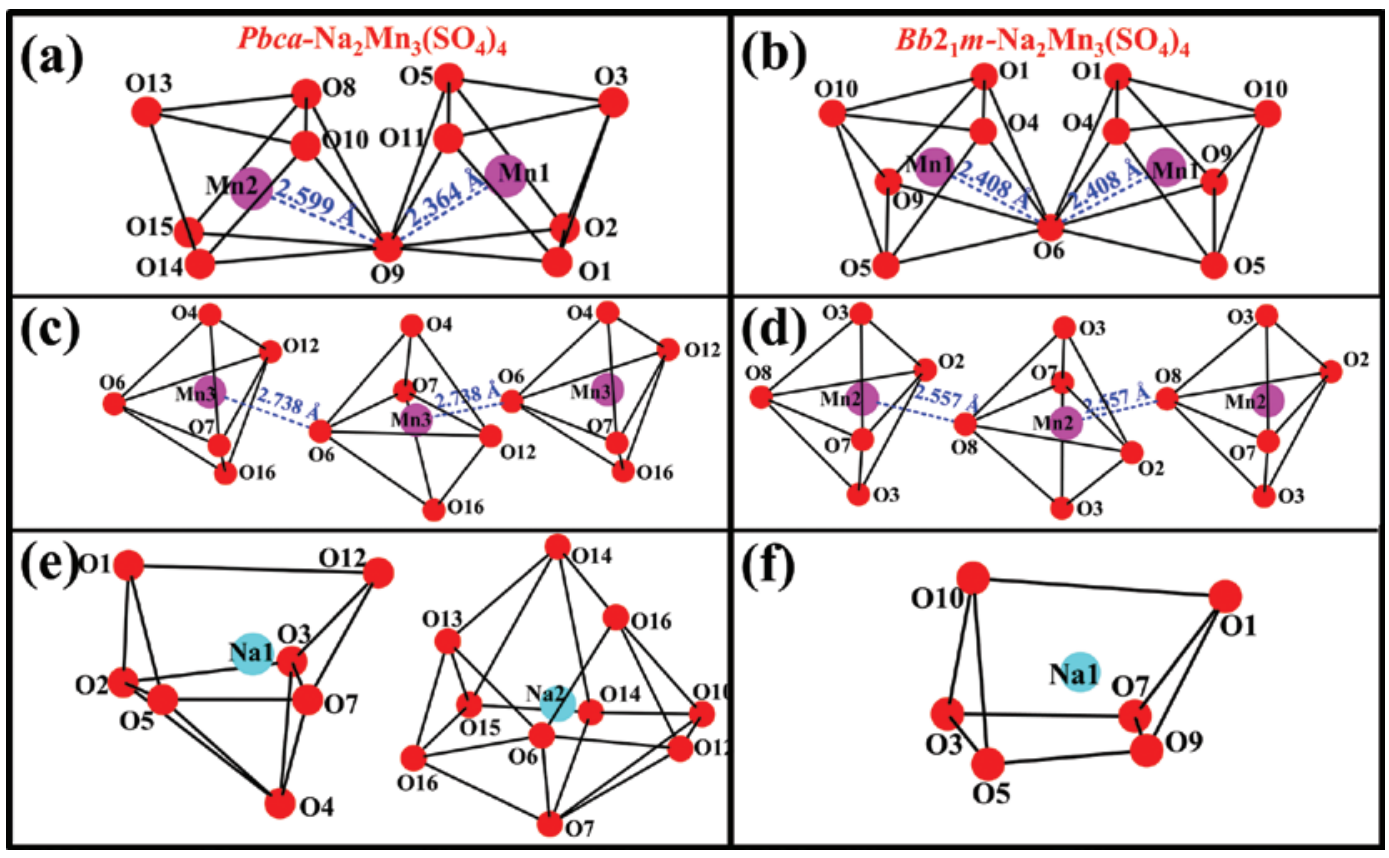

Fig. 4: Coordination polyhedra of the manganese and sodium atoms in the compounds $\mathrm{Pbca}-\mathrm{Na}_{2} \mathrm{Mn}_{3}\left(\mathrm{SO}_{4}\right)_{4}(\mathrm{a}, \mathrm{c}, \mathrm{e})$ and $\mathrm{Bb} 2_{1} \mathrm{~m}$ - $\mathrm{Na}_{2} \mathrm{Mn}_{3}\left(\mathrm{SO}_{4}\right)_{4}$ (b, d, f).
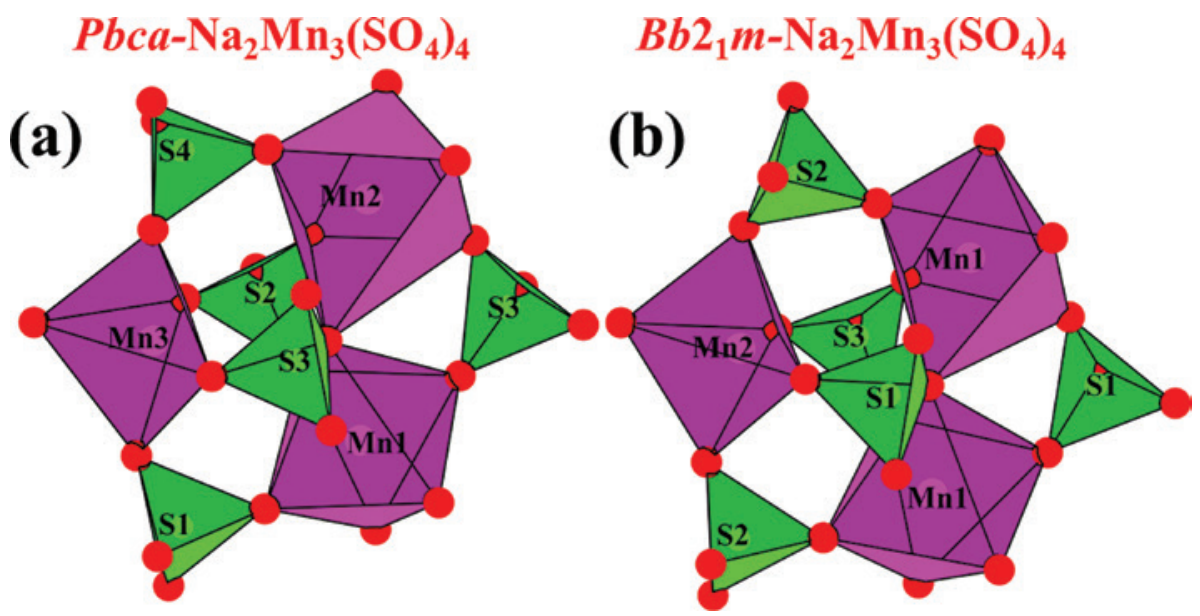

Fig. 5: The connectivity between the $\mathrm{Mn}_{2} \mathrm{O}_{11}$ dimer units, the $\mathrm{MnO}_{5}$ trigonal bipyramids and the $\mathrm{SO}_{4}$ tetrahedra in $\mathrm{Pbca}-\mathrm{Na}_{2} \mathrm{Mn}_{3}\left(\mathrm{SO}_{4}\right)_{4}(\mathrm{a})$ and $\mathrm{Bb}_{1} \mathrm{~m}-\mathrm{Na}_{2} \mathrm{Mn}_{3}\left(\mathrm{SO}_{4}\right)_{4}$ (b).

as a stacking of the sections $\mathbf{A}_{\mathrm{SC}-\mathrm{B}} \mathbf{B}_{\mathrm{SC}-\mathrm{I}} \mathbf{C}_{\mathrm{SC}-\mathrm{I}} \mathbf{D}_{\mathrm{SC}-\mathrm{I}} \mathbf{A}_{\mathrm{SC}-\mathrm{I}}$ (Figure 6a) with the sections $\mathbf{C}_{\mathrm{SC}-\mathrm{I}}$ and $\mathbf{D}_{\mathrm{SC}-\mathrm{I}}$ related by symmetry elements to the sections $\mathbf{A}_{\text {SC-I }}$ and $\mathbf{B}_{\text {SC-I }}$, respectively. On the other hand, the supercell SC-II results from the stacking of the sections $\mathbf{A}_{\mathrm{SC}-\mathrm{II}} \mathbf{B}_{\mathrm{sC}-\mathrm{II}} \mathbf{A}_{\mathrm{sC}-\mathrm{II}} \mathbf{B}_{\mathrm{sC}-\mathrm{II}} \mathbf{A}_{\mathrm{SC}-\mathrm{II}}$ (Figure 6b). It should be noted that the structures should not be considered as layered structures. Dividing the supercells to five sections was performed only to ease the visual comparison of the two structures. Indeed, although the projection views along the $b$ axis of SC-I and SC-II are very similar, the projection views along the $c$ axis of the sections of SC-I and SC-II emphasize several differences (see the sections $\mathbf{C}_{\mathrm{SC}-\mathrm{I}} \mathbf{D}_{\mathrm{SC}-\mathrm{I}}$ and $\mathbf{A}_{\mathrm{SC}-\mathrm{II}} \mathbf{B}_{\mathrm{SC}-\mathrm{II}}$ ). The sections $\mathbf{A}_{\mathrm{SC}-\mathrm{I}}$ and $\mathbf{B}_{\text {SC-I }}$ are almost identical to the sections $\mathbf{A}_{\mathrm{SC}-\mathrm{II}}$ and $\mathbf{B}_{\mathrm{SC}-\mathrm{II}}$, respectively. The $\mathrm{SO}_{4}$ tetrahedra in SC-I are slightly tilted when compared to the tetrahedra in SC-II.

\section{Comparison of the $\mathrm{Pbca}-\mathrm{Na}_{2} \mathrm{Mn}_{3-\mathrm{x}} \mathrm{Mg}_{\mathrm{x}}\left(\mathrm{SO}_{4}\right)_{4}$ compounds}

Starting from the composition $\mathrm{Na}_{2} \mathrm{Mg}_{3}\left(\mathrm{SO}_{4}\right)_{4}$, the total replacement of the $\mathrm{Mg}$ by $\mathrm{Mn}$ atoms was possible and led to an increase of the cell volume from $2435.38(16) \AA^{3}$ to 


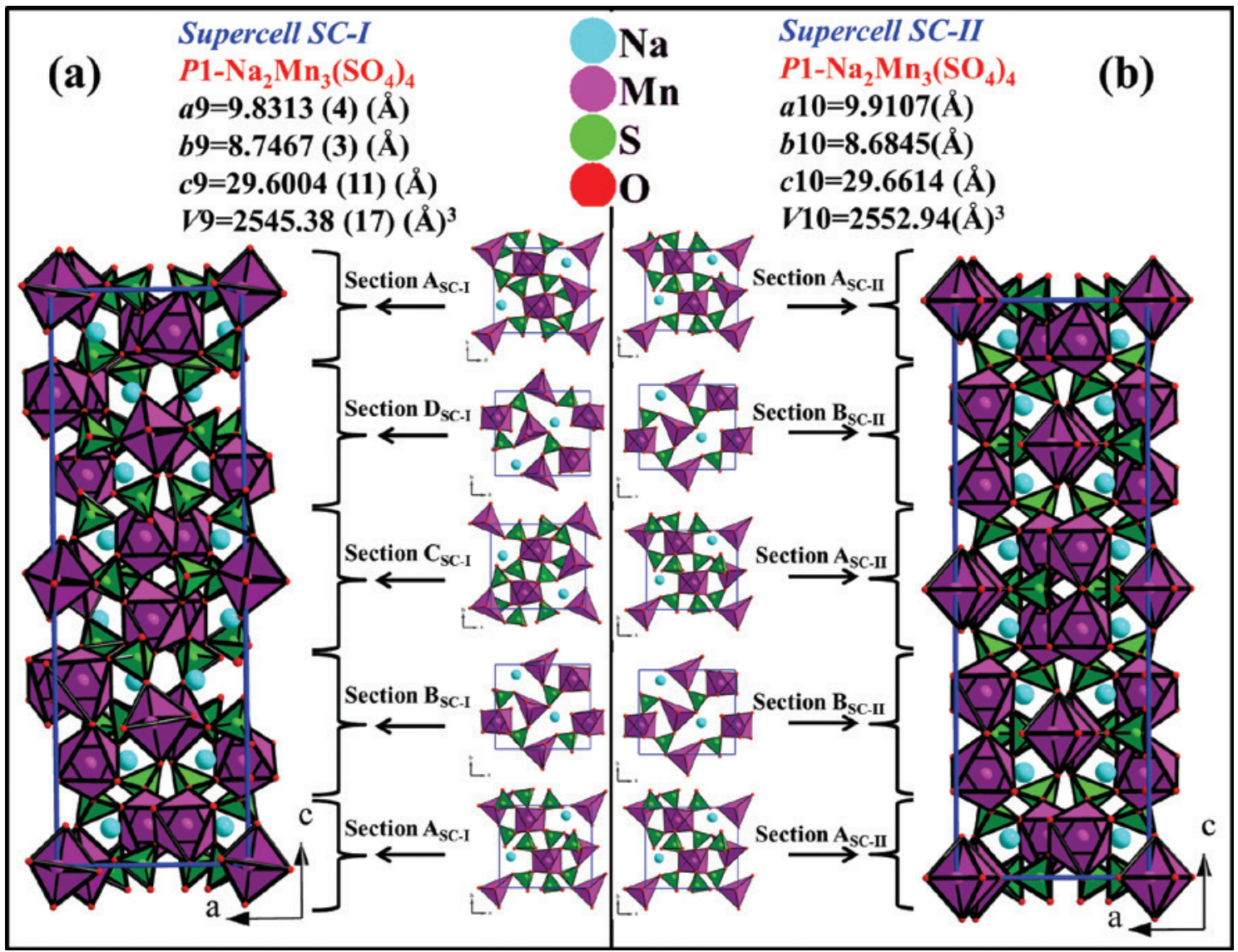

Fig. 6: Projection view along the $b$ axis of the crystal structures of $P b c a-N_{2} \mathrm{Mn}_{3}\left(\mathrm{SO}_{4}\right)_{4}$ (a) and $C m c 2_{1}-\mathrm{Na}_{2} \mathrm{Mn}_{3}\left(\mathrm{SO}_{4}\right)_{4}$ (b) after the transformations to supercells with $P 1$ space group. Projection views along the $c$ axis of different sections are given for comparison. Only the polyhedra arround the $\mathrm{Mn}$ and $\mathrm{S}$ atoms were drawn.

2545.38(17) $\AA^{3}$ of $\mathrm{Pbca}-\mathrm{Na}_{2} \mathrm{Mn}_{3}\left(\mathrm{SO}_{4}\right)_{4}$. The structure did not change, which confirms the existence of a full solid solution between $\mathrm{Na}_{2} \mathrm{Mg}_{3}\left(\mathrm{SO}_{4}\right)_{4}$ and $\mathrm{Na}_{2} \mathrm{Mn}_{3}\left(\mathrm{SO}_{4}\right)_{4}$. In the intermediate phases $\mathrm{Na}_{2} \mathrm{Mg}_{2.5} \mathrm{Mn}_{0.5}\left(\mathrm{SO}_{4}\right)_{4}$ and $\mathrm{Na}_{2} \mathrm{Mg}_{1.5} \mathrm{Mn}_{1.5}\left(\mathrm{SO}_{4}\right)_{4}$ a $\mathrm{Mg} / \mathrm{Mn}$ statistical disorder was observed in all the $\mathrm{Mg}$ sites (Table S4). Using the program Compstru, we investigated and quantified the degree of similarities between the structures of $\mathrm{Pbca}-\mathrm{Na}_{2} \mathrm{Mn}_{3}\left(\mathrm{SO}_{4}\right)_{4}, \mathrm{Pbca}-\mathrm{Na}_{2} \mathrm{Mg}_{2.5} \mathrm{Mn}_{0.5}\left(\mathrm{SO}_{4}\right)_{4}$, Pbca- $\mathrm{Na}_{2} \mathrm{Mg}_{1.5} \mathrm{Mn}_{1.5}\left(\mathrm{SO}_{4}\right)_{4}$ and $\mathrm{Pbca}-\mathrm{Na}_{2} \mathrm{Mg}_{3}\left(\mathrm{SO}_{4}\right)_{4}[33-36]$. Our results that are presented in the Tables S6-S8 confirm that the four compounds are isostructural.

\section{Conclusion}

During the investigation of the binary phase diagram $\mathrm{Na}_{2} \mathrm{SO}_{4}-$ $\mathrm{MgSO}_{4}$ and the crystallization of $\mathrm{Na}_{2} \mathrm{Mg}_{2}\left(\mathrm{SO}_{4}\right)_{3}$, single crystals of $\mathrm{Na}_{2} \mathrm{Mg}_{3}\left(\mathrm{SO}_{4}\right)_{4}$ were isolated. Thereafter, the $\mathrm{Mg}$ atoms were gradually replaced by $\mathrm{Mn}$ and single crystals of three new compounds could be grown using self-flux method. Interestingly, the four prepared compounds $\mathrm{Na}_{2} \mathrm{Mg}_{3}\left(\mathrm{SO}_{4}\right)_{4}$,
$\mathrm{Na}_{2} \mathrm{Mg}_{2.5} \mathrm{Mn}_{0.5}\left(\mathrm{SO}_{4}\right)_{4}, \quad \mathrm{Na}_{2} \mathrm{Mg}_{1.5} \mathrm{Mn}_{1.5}\left(\mathrm{SO}_{4}\right)_{4}$ and $\mathrm{Na}_{2} \mathrm{Mn}_{3}\left(\mathrm{SO}_{4}\right)_{4}$ are isostructural and crystallize in the space group $\mathrm{Pbca}$ which confirms the existence of a full solid solution between $\mathrm{Na}_{2} \mathrm{Mg}_{3}\left(\mathrm{SO}_{4}\right)_{4}$ and $\mathrm{Na}_{2} \mathrm{Mn}_{3}\left(\mathrm{SO}_{4}\right)_{4}$ and the existence of a second polymorphic modification of $\mathrm{Na}_{2} \mathrm{Mn}_{3}\left(\mathrm{SO}_{4}\right)_{4}$. It should be mentioned that the previously described polymorph of $\mathrm{Na}_{2} \mathrm{Mn}_{3}\left(\mathrm{SO}_{4}\right)_{4}$ crystallizes in the space group $\mathrm{Cmc2}_{1}\left(\mathrm{Bb}_{1} \mathrm{~m}\right)$. The use of group-subgroup schemes in the Bärnighausen formalism enabled an accurate structural comparison of the $\mathrm{Pbca}$ - and $\mathrm{Cmc2}_{1}$-polymorphs of $\mathrm{Na}_{2} \mathrm{Mn}_{3}\left(\mathrm{SO}_{4}\right)_{4}$. Although, the crystal strucures of both polymorphs are different, they share similar features: they contain the same building blocks $\mathrm{Mn}_{2} \mathrm{O}_{11}$ dimer units and $\mathrm{MnO}_{5}$ trigonal pyramids that are interconnected by sharing corners with the $\mathrm{SO}_{4}$ tetrahedra.

Acknowledgements: Authors would like to thank Dr. Said Mansour for giving us access to the characterization tools in the core lab. The authors also would like to thank the reviewers who have made substantial efforts to improve the article. The publication of this article was funded by the Qatar National Library. 


\section{References}

[1] S.-P. Guo, J.-C. Li, Q.-T. Xu, Z. Ma, H.-G. Xue, Recent achievements on polyanion-type compounds for sodium-ion batteries: Syntheses, crystal chemistry and electrochemical performance. J. Power Sources 2017, 361, 285.

[2] J.-Y. Hwang, S.-T. Myung, Y.-K. Sun, Sodium-ion batteries: present and future. Chem. Soc. Rev. 2017, 46, 3529.

[3] P. Barpanda, G. Oyama, C. D. Ling, A. Yamada, Kröhnkite-type $\mathrm{Na}_{2} \mathrm{Fe}\left(\mathrm{SO}_{4}\right)_{2} \cdot 2 \mathrm{H}_{2} \mathrm{O}$ as a novel $3.25 \mathrm{~V}$ insertion compound for $\mathrm{Na}-$ Ion batteries. Chem. Mater. 2014, 26, 1297.

[4] M. Reynaud, G. Rousse, A. M. Abakumov, M. T. Sougrati, G. Van Tendeloo, J. N. Chotard, J. M. Tarascon, Design of new electrode materials for Li-ion and $\mathrm{Na}$-ion batteries from the bloedite mineral $\mathrm{Na}_{2} \mathrm{Mg}\left(\mathrm{SO}_{4}\right)_{2} \cdot 4 \mathrm{H}_{2} \mathrm{O}$. J. Mater. Chem. 2014, A2, 2671.

[5] P. Barpanda, G. Oyama, S. Nishimura, S.-C. Chung, A. Yamada, A 3.8-V earth-abundant sodium battery electrode. Nature Commun. 2014, 5, 4358

[6] G. Oyama, S. Nishimura, Y. Suzuki, M. Okubo, A. Yamada, Off-stoichiometry in alluaudite-type sodium iron sulfate $\mathrm{Na}_{2+2 \mathrm{x}} \mathrm{Fe}_{2-\mathrm{x}}\left(\mathrm{SO}_{4}\right)_{3}$ as an advanced sodium battery cathode material. Chem. Electrochem. 2015, 2, 1019.

[7] G. Oyama, O. Pecher, K. J. Griffith, S. Nishimura, R. Pigliapochi, C. P. Grey, A. Yamada, Sodium intercalation mechanism of 3.8 V class alluaudite sodium iron sulfate. Chem. Mater. 2016, 28, 5321.

[8] P. Singh, K. Shiva, H. Celio, J. B. Goodenough, Eldfellite, $\mathrm{NaFe}\left(\mathrm{SO}_{4}\right)_{2}$ : an intercalation cathode host for low-cost Na-ion batteries. Energy Environ. Sci. 2015, 8, 3000.

[9] K. L. Keester, W. Eysel, New compounds $\mathrm{MNa}_{6}\left(\mathrm{SO}_{4}\right)_{4}$ with vanthoffite structure. Acta Crystallogr. B 1977, 33, 306.

[10] D. Swain, T. N. Guru Row, In situ phase separation following dehydration in bimetallic sulfates: a variable-temperature X-ray diffraction study. Inorg. Chem. 2009, 48, 7048.

[11] D. Marinova, V. Kostov, R. Nikolova, R. Kukeva, E. Zhecheva, M. Sendova-Vasileva, R. Stoyanova, From kröhnkite- to alluauditetype of structure: novel method of synthesis of sodium manganese sulfates with electrochemical properties in alkali-metal ion batteries. J. Mater. Chem. 2015, A3, 22287.

[12] D. Dwibedi, R. B. Araujo, S. Chakraborty, P. P. Shanbogh, N. G. Sundaram, R. Ahuja, P. Barpanda, $\mathrm{Na}_{2.44} \mathrm{Mn}_{1.79}\left(\mathrm{SO}_{4}\right)_{3}$ : a new member of the alluaudite family of insertion compounds for sodium ion batteries. J. Mater. Chem. 2015, A3, 18564.

[13] E. Matzat, Die Kristallstruktur des Natrium-Mangan-Doppelsulfats $\mathrm{Mn}_{7} \mathrm{Na}_{12}\left(\mathrm{SO}_{4}\right)_{13} \cdot 15 \mathrm{H}_{2} \mathrm{O}$. Neues Jahrb. Mineral Abh. 1970, 113, 1.

[14] A. V. Kasatkin, M. Favaro, S. Bianchin, I. S. Lykova, V. Golias, W. D. Birch, F. Nestola, J. Plasil, J. Marty, D. I. Belakovskiy, A. A. Agakhanov, S. J. Mills, D. Pedron, A. Lanza, Manganoblödite, $\mathrm{Na}_{2} \mathrm{Mn}\left(\mathrm{SO}_{4}\right)_{2} \cdot 4 \mathrm{H}_{2} \mathrm{O}$, and cobaltoblödite, $\mathrm{Na}_{2} \mathrm{Co}\left(\mathrm{SO}_{4}\right)_{2} \cdot 4 \mathrm{H}_{2} \mathrm{O}$ : two new members of the blödite group from the Blue Lizard mine, San Juan County, Utah, USA. Mineral. Mag. 2013, 77, 367.

[15] J. Gao, X. Sha, X. Liu, L. Song, P. Zhao, Preparation, structure and properties of $\mathrm{Na}_{2} \mathrm{Mn}_{3}\left(\mathrm{SO}_{4}\right)_{4}$ : a new potential candidate with high voltage for Na-ion batteries. J. Mater. Chem. 2016, A4, 11870.

[16] H. Ben Yahia, R. Essehli, R. Amin, K. Boulahya, T. Okumura, I. Belharouak, Sodium intercalation in the phosphosulfate $\mathrm{NaFe}_{2}\left(\mathrm{PO}_{4}\right)\left(\mathrm{SO}_{4}\right)_{2}$. J. Power Sources 2018, 382, 144.
[17] R. Essehli, H. Ben Yahia, K. Maher, M. T. Sougrati, A. Abouimrane, J.-B. Park, Y.-K. Sun, M. A. Al-Maadeed, I. Belharouak, Unveiling the Sodium Intercalation Properties in $\mathrm{Na}_{1.8600 .14} \mathrm{Fe}_{3}\left(\mathrm{PO}_{4}\right)_{3}$. J. Power Sources 2016, 324, 657.

[18] H. Ben Yahia, M. Shikano, M. Tabuchi, I. Belharouak, Synthesis, crystal structure, and properties of the alluaudite-type vanadates $\mathrm{Ag}_{2-\mathrm{x}} \mathrm{Na}_{\mathrm{x}} \mathrm{Mn}_{2} \mathrm{Fe}\left(\mathrm{VO}_{4}\right)_{3}$. Inorg. Chem. 2016, 55, 4643.

[19] H. Ben Yahia, R. Essehli, M. Avdeev, J.-B. Park, Y.-K. Sun, M. A. Al-Maadeed, I. Belharouak, Neutron diffraction studies of the na-ion battery electrode materials $\mathrm{NaCoCr}\left(\mathrm{PO}_{4}\right)_{3}, \mathrm{NaNiCr}_{2}\left(\mathrm{PO}_{4}\right)_{3}$, and $\mathrm{Na}_{2} \mathrm{Ni}_{2} \mathrm{Cr}\left(\mathrm{PO}_{4}\right)_{3}$. J. Solid State Chem. 2016, 238, 103.

[20] R. Essehli, I. Belharouak, H. Ben Yahia, K. Maher, A. Abouimrane, B. Orayech, S. Calder, X. L. Zhou, Z. Zhou, Y.-K. Sun, Alluaudite $\mathrm{Na}_{2} \mathrm{Co}_{2} \mathrm{Fe}\left(\mathrm{PO}_{4}\right)_{3}$ as electroactive material for sodium ion batteries. Dalton Trans. 2015, 44, 7881.

[21] R. Essehli, I. Belharouak, H. Ben Yahia, R. Chamoun, B. Orayech, B. El Bali, K. Bouziane, X. Zhou, Z. Zhen, $\alpha-\mathrm{Na}_{2} \mathrm{Ni}_{2} \mathrm{Fe}\left(\mathrm{PO}_{4}\right)_{3}:$ a dual positive/negative electrode material for sodium ion batteries. Dalton Trans. 2015, 44, 4526.

[22] H. Ben Yahia, D. Mori, M. Shikano, H. Kobayashi, Y. Inaguma, Structural, magnetic, and electrochemical properties of the high pressure form of $\mathrm{Na}_{2} \mathrm{Co}\left[\mathrm{PO}_{4}\right] \mathrm{F}$. Dalton Trans. 2014, 43, 13630.

[23] H. Ben Yahia, M. Shikano, H. Sakaebe, S. Koike, M. Tabuchi, $\mathrm{H}$. Kobayashi, New fluorophosphate $\mathrm{Li}_{2-\mathrm{x}} \mathrm{Na}_{\mathrm{x}} \mathrm{Fe}\left[\mathrm{PO}_{4}\right] \mathrm{F}$ as cathode material for lithium ion battery. J. Power Sources 2013, 244, 87.

[24] I. A. Trussov, L. L. Male, M. L. Sanjuan, A. Orera, P. R. Slater, Understanding the complex structural features and phase changes in $\mathrm{Na}_{2} \mathrm{Mg}_{2}\left(\mathrm{SO}_{4}\right)_{3}$ : a combined single crystal and variable temperature powder diffraction and Raman spectroscopy study. J. Solid State Chem. 2019, 272, 157.

[25] V. Petricek, M. Dusek, L. Palatinus, Crystallographic computing system JANA2006: general features. Z. Kristallogr. 2014, 229, 345.

[26] Bruker. APEX3, SAINT and SADABS. Bruker AXS Inc., Madison, Wisconsin, USA, 2016.

[27] L. Palatinus, G. Chapuis, SUPERFLIP - a computer program for the solution of crystal structures by charge flipping in arbitrary dimensions. J. Appl. Cryst. 2007, 40, 786.

[28] I. D. Brown, D. Altermatt, Bond-valence parameters obtained from a systematic analysis of the Inorganic Crystal Structure Database. Acta Crystallogr. 1985, B41, 244.

[29] R. D. Shannon, Revised effective ionic radii and systematic studies of interatomic distances in halides and chalcogenides. Acta Crystallogr. 1976, A32, 751.

[30] H. Bärnighausen, Group-subgroup relations between space groups: a useful tool in crystal chemistry. Commun. Math. Chem. 1980, 9, 139.

[31] H. Bärnighausen, U. Müller, Symmetriebeziehungenzwischen den RaumgruppenalsHilfsmittelzurstraffenDarstellung von Strukturzusammenhängen in der Kristallchemie, University of Karlsruhe and University/GH Kassel, 1996.

[32] U. Müller, KristallographischeGruppe-Untergruppe-Beziehungen und ihreAnwendung in der Kristallchemie. Z. Anorg. Allg. Chem. 2004, 630, 1519.

[33] G. de la Flor, D. Orobengoa, E. Tasci, J. M. Perez-Mato, M. I. Aroyo, Comparison of structures applying the tools available at the Bilbao Crystallographic Server. J. Appl. Crystallogr. 2016, 49, 653. 
[34] C. Capillas, J. M. Perez-Mato, M. I. Aroyo, Maximal symmetry transition paths for reconstructive phase transitions. J. Phys.: Condens. Matter 2007, 19, 275203.

[35] D. Orobengoa, C. Capillas, M. I. Aroyo, J. M. Perez-Mato, AMPLIMODES: symmetry-mode analysis on the Bilbao Crystallographic Server. J. Appl. Crystallogr. 2009, 42,820 .
[36] G. Bergerhoff, M. Berndt, K. Brandenburg, T. Degen, Concerning inorganic crystal structure types. Acta Crystallogr. 1999, B55, 147.

Supplementary Material: The online version of this article offers supplementary material (https://doi.org/10.1515/zkri-2019-0038). 